Journal of Economics and Behavioral Studies

Vol. 6, No. 2, pp. 120-129, Feb 2014 (ISSN: 2220-6140)

\title{
Against the Herd: Contrarian Investment Strategies on the Johannesburg Stock Exchange
}

\author{
Prince K. Sarpong, *Mabutho Sibanda \\ University of KwaZulu-Natal, Durban, South Africa \\ *sibandam@ukzn.ac.za
}

\begin{abstract}
This study seeks to investigate herd behaviour among equity mutual fund managers and the performance of mutual funds that trade against the herd in South Africa. The behaviour of mutual funds has an effect on the stability and volatility of stock markets, the ultimate returns to the investors. The study builds upon the efficient market hypothesis, portfolio theory and behavioural finance to provide evidence of the behaviour of mutual funds in an emerging market context using the Johannesburg Stock Exchange. The Lakonishok, Shleifer and Vishney (1991) measure of herding is used to ascertain the behaviour of mutual funds over the period 2006 to 2012. Institutional investors in South Africa are susceptible to the behavioural bias of herding and this phenomenon influences the performance of their funds. Funds that trade in the opposite direction of herd funds are able to put up a superior performance over time. Superior performance, however, does not entice mutual fund investors to invest less in under-performing funds and more in funds that recently show superior performance. These findings imply that following investment waves does not culminate in superior returns in the stock market. Consequently, mutual funds that take an opposite direction to herd funds help stabilize the stock market and lessen the severity of bear markets. This study categorizes mutual funds into 'herding' and 'contrarian' and provides an insight into the performance of each category. Investors who oppose herd behaviour realize greater returns over time while stabilizing the markets at the same time.
\end{abstract}

Keywords: Classical Finance; Behavioural finance; Herding; Contrarian funds, mutual funds

\section{Introduction}

Investment management is a growing field in finance that is mainly boosted by globalization and the integration of world markets. Investment management and its strategies have led to growth in the number of investment vehicles and products within finance globally. One such important vehicle used in modern financial markets is the mutual funds industry. Mutual funds are a popular investment vehicle for diverse investors for several reasons. A major reason for investing in mutual funds is diversification, as mutual funds best meet the investment cliché of not putting one's eggs in one basket by offering investors a portfolio of several assets. Furthermore, mutual funds provide the benefit of expert decision-making as they are managed by highly qualified investment professionals whilst lowering the cost of investing in financial markets(Hall, 2010). Investors are therefore assured of quality investment services, which they otherwise may only obtain at a higher cost. Mutual fund managers are either active investors or passive investors. Active investors seek to outperform the market, whereas passive investors follow a "buy-and-hold" investment strategy(Haslem, 2009). In executing their mandates, active mutual fund managers may either take independent strategies, herd, or take contrarian investment strategies in the quest to beat the market. According to the Standard and Poor's (S\&P) Indices' 10th annual fund performance scorecard, around 84\% of U.S. stock funds under active management underperformed S \& P's indexes in 2011(Karaban \& Maguire, 2012). In South Africa, mutual funds are referred to as unit trusts and are managed through the Collective Investment Schemes Control Act No. 45 of 2002, which falls under the auspices of the Financial Services Board (FSB). Only the structure differentiates mutual funds from unit trusts, but the end result for the investor is the same (Damodaran, 2012).Consequently, in this study we use the term mutual fund to refer to unit trusts. The first mutual funds in South Africa were created in 1965 and the industry has been growing ever since (Damodaran, 2012). The total assets of mutual funds in South Africa in December 2012 (excluding fund of funds) - according to the Association for Savings and Investment South Africa (ASISA) - was R1.16 trillion, which was approximately $15 \%$ of the total market capitalization of the Johannesburg Stock Exchange in 2012, growing from R78.8 billion in 1998, which was $7.9 \%$ of the total market capitalization of the Johannesburg Stock Exchange in 
1998. The trend in the growth of mutual funds shows the relative importance of the industry in promoting retail investments in South Africa.

Mutual fund managers adopt different investment strategies with the aim of achieving superior performance. Some managers are active traders whereas others are passive investors(Haslem, 2009). Active investors apply different investment strategies and philosophies in executing their mandates. Two common strategies are contrarian and momentum strategies. Momentum investors believe price trends will persist and believe in buying high and selling at an even higher price(Schwager, 2012). This strategy tends to attract huge adherents (crowds/herd) as uninformed investors also jump unto the bandwagon to make profits. For all investors who have a tendency to go along with the crowd too much - momentum investors - there is an assumption that there are investors who move in the opposite direction, that is, contrarian investors, and while such a strategy could be a reasonable supposition for the long term, in the short term, it may not be a realistic one (Damodaran, 2012). This study therefore seeks to investigate whether mutual funds investors herd in their investment behaviour and the consequences of such behaviour on the funds' performance. Funds are categorised as herd funds (funds that trade in the direction of the majority) and contrarian funds funds that trade in the opposite direction of the herd funds. The study provides significant insights into the trading patterns of mutual funds and how such patterns are likely to influence the markets in both bearish and bullish conditions. The insights derived from this paper should further drive policy formulation with respect to mutual funds asset holdings and trading activities thereof. In addition, findings from this study provide expedient knowledge and understanding of the behaviour of mutual funds to the investing public especially in the context of emerging markets.

\section{Literature Review}

Existing studies have shown how the majority of mutual fund managers consistently under-perform relative to their respective benchmarks (Jensen, 1968; Quigley \& Sinquefield, 2000; Ang, Goetzmann \&Schaefer, 2010). Mutual fund managers and investors in general, who are known to consistently beat the market, attribute their success to unique investment strategies. Warren Buffet is known for picking stocks which he deems under-valued (value investing) by applying, inter alia, price multiples such as Price to Earnings (P/E) ratio, and Price to Book (P/B) ratio(Swedroe, 2012). David Dreman is well known for his strategy of buying when the popular sentiment in the market is to sell and selling when the popular sentiment is to buy (contrarian strategy) (Dreman, 2012). Richard Driehaus' strategy is based on "buying high and selling at even higher prices" a strategy popularly referred to as momentum strategy(Damodaran, 2012; Schwager, 1992). Even though one of the basic assumptions of classical finance and economics is that investors are rational(Yalçın, 2010), behavioural finance theorists have come up with empirical evidence to prove that in making investment decisions, investors are prone to certain behavioural biases that leads them to making less than optimal decisions(Kahneman, Slovic \& Tversky, 1892, Lee, O’Brien \& Sivaramakrishnan, 2010). Studies in behavioural finance have shown that investors (both individual and institutional) sometimes base their investment decisions on the actions of the majority, and therefore are inclined to follow the trend as opposed to utilizing information available to them(Scharfstein \& Stein, 1990; Sias, 2004, Baddeley, Burke, Schultz \&Tobler, 2012). This behaviour is referred to as herding and has been extensively studied in many advanced and emerging markets. For instance, studies have shown the existence of high level of herding in emerging markets (Bowe \& Domuta, 2004; Gilmour \& Smit, 2002; Lobao \& Serra, 2002).There are also investors whose strategy involves trading on the opposite side of the herd, i.e., buying when the herd is selling, and selling when the herd is buying. As already mentioned, these investors are known as contrarian investors (Dreman, 2012; Loughran, 2012).

Contemporary literature shows that two measures of herding and mutual funds strategies have been widely accepted. These two methods are those developed by Lakonishok, Shleifer \& Vishny (1991), known as the LSV measure, and Christie and Huang (1995). Lakonishok et al. (1991) pioneered the measuring of correlated trading by institutional investors with their now widely used LSV measure, which seeks to measure whether or not more investors are trading on either the buy side or sell side of the market than would normally be expected if market participants traded independently. They studied the investment behaviour of 341 fund managers in charge of 764 tax-exempt equity funds and found that herd behaviour exists among institutional investors albeit very minimal. On the other hand, Christie and Huang (1995) developed an intuitive herding 
measure utilizing cross-sectional standard deviation (CSSD) of single stock returns with regards to market returns. Their study focused on measures of dispersion during periods of significant variations in stock prices. They assert that such periods are uniquely informative as there is a high probability to herd in stressful markets as individual investors are likely to discard their own beliefs and follow market consensus. Demirer, Kutanand \& Chen (2006) analysed individual stock returns for firms and sector returns over the period 1999 to 2002 to investigate herd behaviour in the stock market of China. Their results found no evidence of herding in the Chinese market; they also stated that the Asian crisis period did not significantly affect cross-sectional standard deviations. However, in contrast, Tan, Chiang, Mason and Nelling (2008) assert that there is evidence of herd behaviour in both the Shanghai and Shenzhen markets for A-shares. Their study, which covered the period 1996 to 2003, also found that herd behaviour is a short-term phenomenon. Tan et al. (2008) found evidence of intense herding in the Shanghai market when there are high trade volumes, high volatility and a rising market. During periods of intense price volatility in the Chinese markets, foreign investors in the Shanghai-B and Shenzhen-B shares adopt the strategy of trading in response to signals other than fundamentals due to lack of fundamental and private information from firms listed on these markets (Chen, Rui \& Zu, 2003). The Shanghai-B and Shenzhen-B equity investors are foreign investors who tend to herd as a result of inefficient information disclosure. Among A-share investors on both the Shanghai-A and Shenzhen-A, however, Chen et al. (2003) find mixed and weaker evidence to imply herding behaviour over the period January 1996 to December 2002. This suggests that herding may be evident in volatile markets, which have become more common in the modern era.

Furthermore, Lakshman, Basu and Vaidyanathan (2008)found that herding has been on a decreasing trend and significance in the Indian market after 2006. However, herd behaviour was prevalent from 2003 to 2005 and herding was prevalent before market stress rather than during market stress. They further suggested that market stress can rather help bring the market to equilibrium. Consistent with the findings of Lakshman et al. (2008), Prosad, Kapoor and Sengupta (2012) found no evidence of herding in the Indian Stock Market over the period 2006 to 2011 using a sample of Nifty50 stocks (a stock index for 22 sectors of the economy of India). Contrary to the findings above, Farber, Nguyen \& Vuong (2006) confirmed the existence of herding on the Ho Chi Minh City Securities Trading Center (HSTC) in Vietnam in stressful market conditions. Moreover, Farber et al. (2006) used the Christie and Huang (1995) method of measuring herding, over the period 2000 to 2006 and found significant herd impact on huge positive returns on market portfolio. In the South African context, Gilmour and Smit (2002) applied the herd measure proposed by Lakonishok et al. (1991), and documented the existence of relatively low levels of herding among institutional investors. Aggressive growth funds were found to have the highest level of herding, suggesting that a significant positive relationship exists between the level of herding and the risk profile of funds on the Johannesburg Stock Exchange (JSE). Over the period 1992 to 1999, herding occurred both on the buy side and sell side. However, the study by Gilmour and Smit was based on a period when only domestic mutual funds operated in the country. International mutual funds were allowed in South Africa in 1998, and since then the industry has recorded phenomenal growth. As a consequence the behaviour of mutual funds might have changed over the past decade.

On the opposite side of the herd behavioural strategies are the contrarian investment strategies, which posit that investors oppose the market or other investors in their investment actions. A study by De Bondt and Thaler (1985) concluded that there is the existence of price reversal for stocks that undergo long periods of gains or losses thereby confirming the potency of contrarian strategies to provide higher returns when compared to momentum or growth strategies. They reiterate the contrarian mantra of past winners underperforming past losers. They attribute such a reversal in performance to overreaction on the side of investors who beat down the price of value stocks beyond intrinsic value by selling such stocks because of poor performance, which they expect to persist while buying glamour stocks due to their good run, which they expect to continue. The study examined an investment strategy based on the notion that investors overreact to earnings, therefore causing stock prices to depart temporarily from their fundamentals with prices affected by excessive optimism or pessimism. In a follow up paper, De Bondt and Thaler (1987) report additional evidence to support their overreaction hypothesis. The study points out a significant seasonality in "price correction" with the majority of such corrections occurring successively in the months of January and mostly for loser stocks, and the correction seems asymmetric as loser stocks gain approximately three times the amount that winner stocks lose after the date of the portfolio formation. Applying the same technique as De Bondt and Thaler (1985), Clare and Thomas (1995) conducted a study on the United Kingdom (UK) 
financial market over the period 1955 to1980 and concluded that loser stocks outperformed winner stocks by a significant margin of $1.7 \%$ but such outperformance is as a result of differences in firm size, and as such there is no evidence of overreaction on the UK stock market.

Moreover, De Haan and Kakes (2011), in a study on the investment strategies of life insurers, non-life insurers and pension funds on Dutch institutional investors over the period 1999 - 2005, discovered that all three institutional traders, especially pension funds, were contrarian traders and had a stabilizing effect on the Dutch financial market when needed the most. They stated that life insurers adopt a contrarian strategy any time they have a high percentage of unit-linked policies, while non-life insurers adopt contrarian strategies when they have riskier business models. Also, Petersen and Arnstedt (2010), in a study on the American stock market over the period 1947 to 2009, noted that sorting by book-to-market values, value premium existed throughout the period of investigation with an average quarterly premium of more than $3 \%$ with value stocks exhibiting a higher upside potential when compared to growth stocks. The study further states that value stocks perform poorly in the period immediately preceding and during recessions than on average, but there are positive value premiums in 10 out of 11 different recessions over the four quarters after recessions, indicating a strong tendency for higher returns for value stocks after recessions. There is therefore strong evidence in favour of contrarian strategies, making it essential for investors seeking superior returns over time to consider this strategy.

Finally, Fluck, Malkiel and Quandt (1997) in a study spanning 13 years over the 1980s and early 1990s, found stocks with poor returns during the previous three to five years posted higher returns in the subsequent period. The study was conducted by buying stocks that had low returns over the three to five years. Stock with higher returns over the previous three to five years, on the other hand, experienced lower returns over the subsequent period, confirming strong statistical evidence of the reversal of returns. The study was unable to confirm however, that the contrarian approach was a superior strategy as the performance for both groups were not very different. Wei, Wermers and Yao (2008) in their study on herding and fund performance in the United States, ranked funds according to their contrarian index, which measures the extent to which a fund manager deviated from the herd and found that contrarian funds outperform herd funds by an average of 2.6\% per annum. Gupta-Mukherjee (2012) further documents underperformance of fund managers that deviate from their peers. The study formed a hypothetical portfolio selected by an imaginary representative fund manager (RM). The RM is the illustrative proxy of a group of competing fund managers with the portfolio reflecting the RM's beliefs with regards to future asset prices. Gupta-Mukherjee (2012) however, points out a dissipation of outperformance after two quarters. Even though herd behavior among institutional investors has been widely studied in several markets, both emerging and developed, little attention is paid to the effect of herding on the performance of the portfolios of these investors. If herding affects stock prices, then the subsequent performance of portfolios will in turn be affected by this phenomenon and therefore it becomes imperative to investigate how herding impacts portfolio performance.

\section{Methodology}

Data: We analyse quarterly portfolio holdings of 41 domestic equity funds. Quarterly mutual fund holdings and mutual funds returns are obtained from the database of Profile Data. Profile Data undertakes research and supplies financial data including data on mutual funds in South Africa. The samples selected for this study are from the population of all actively managed South African general equity portfolios available on the Profile Data's database. The sample funds are taken from a population of 152(as at December 2012) actively managed South African general equity portfolios and as such index funds are not considered consistent with Sonaer (2011). Fund of funds are excluded as well, with the aim of avoiding double counting. Sector funds and Islamic funds are also excluded from this study as well as all funds with less than $80 \%$ domestic equity holdings. We define South African equity portfolios as those funds with at least $80 \%$ of their portfolio invested in equities with capital appreciation as the primary objective in line with the ASISA definition. South African general equity portfolios are defined by ASISA as portfolios that invest in a number of shares across all industry groups as well as over a selection of large-, mid- and small-cap equities.

LSV Measure: The mission in investigating herd behaviour among fund managers is to examine the independence of fund managers' portfolio modifications, while taking cognisance of objects of portfolio optimization issues that are not herding; it is only when independence is rejected that we can sum up the 
extent of common dependence between the transactions of the fund managers in the group. The LSV measure reflects observations where the result of a transaction is a buy or sells. After this conditioning, in the event of a transaction, the said trading direction is the result of a Bernoulli trial with probability bound

$$
\mathrm{p}_{i t}^{\mathrm{j}}=\operatorname{Prob}\left(\mathrm{X}_{i t}^{\mathrm{j}}=\text { buy } \mid \mathrm{X}_{i t}^{\mathrm{j}}=\text { buy or } \mathrm{X}_{i t}^{\mathrm{j}}=\text { sell }\right)
$$

wherep ${ }_{i t}^{\mathrm{j}}$ is the probability of a fund manager $j$ to buy stock iat period $t$ (Wylie, 2005). An assumption inherent in the LSV measure is that where there is no herding, the propensity to buy is invariant for all fund managers and stocks in any given period so thatp $\mathrm{p}_{i t}^{\mathrm{j}}=\mathrm{p}_{t}, \forall i, j$. Each of the Bernoulli trials is independent of all other trials. The null hypothesis of the LSV measure is that in the absence of herding, the ratio of buys to trades has the same expected value $p(t)$ for all stocks in any one period (Wylie, 2005). The LSV Measure of herding for a given stock in a given quarter $\mathrm{HM}_{i, t}$ is given as:

$H M_{i, t}=\left|\frac{B_{i, t}}{\left[B_{i, t}+S_{i, t}\right]}-p(t)\right|-A F_{i, t}$

Where:

$\mathrm{B}_{i, t}=$ number of money managers who increase their holdings in the quarter (net buyers),

$\mathrm{S}_{i, t}=$ number of money managers who decrease the holdings in the quarter (net sellers),

$p(t)=$ expected proportion of money managers buying in that quarter relative to the number active.

$\mathrm{AF}_{i, t}=$ the expected value of $\left|\frac{B_{i, t}}{\left[B_{i, t}+S_{i, t}\right]}-p(t)\right|$ under the null hypothesis of no herding

$\mathrm{AF}$ accounts for the fact that under the null hypothesis of no herding, i.e., when the probability of any manager being a net buyer of any stock is $p$, the absolute value of $\left|\frac{B_{i, t}}{\left[B_{i, t}+S_{i, t}\right]}-p(t)\right|$ is greater than zero. For any stock, $\mathrm{AF}$ declines as the number of money managers active in that stock rises.

In line with Wermers (1999), a stock must be traded by at least five funds during a given a quarter in arriving at the LSV measure.

The value of $\left|\frac{B_{i, t}}{\left[B_{i, t}+S_{i, t}\right]}-p(t)\right|$ will be large if the transaction of mutual fund managers in stock $i$ in period $t$ is skewed in the path of either buying or selling. The overall herding measure $H M_{i, t}$ is the simple average of the statistic over all the periods under consideration.

The LSV measure does not indicate the direction of the herding. To determine the level of the buy and sell herding, Wermers (1999) proposed conditional buy $\left(B H M_{i, t}\right)$ and sell herd measures $\left(S H M_{i, t}\right)$. If $p_{i, t}>\bar{p}_{t}$, i.e., if the ratio of mutual fund buys is greater than average for the given quarter, the stock is classified as a "buyherd" stock. In the same way, equities with $p_{i, t}<\bar{p}_{t}$ are categorised as "sell-herd" stocks where $p_{i, t}=\frac{B_{i, t}}{\left[B_{i, t}+S_{i, t}\right]}$. The measures are calculated as:

$B H M_{i, t}=H M_{i, t} \mid p_{i, t}>\bar{p}_{i, t}$

$S H M_{i, t}=H M_{i, t} \mid p_{i, t}<\bar{p}_{i, t}$

All "buy-herd" stocks are ranked into quintiles according to their buy-herd measure and given a rank of 1 through to 5 to the quintiles. The rank measure, $R B H M_{i, t}$, will be equal to 5 for stocks that were the most heavily purchased by mutual funds herds with reference to Equation (2). In the same way, the study ranks "sell-herding" stocks into quintiles according to their sell-herd measures with $R_{S H} M_{i, t}$ assigned 5 for stocks that were sold the most by herds, through to 1 for stocks that were the least sold. This ranking style minimizes the effect of outliers (intense buy or sell herding).

Contrarian Index: The study further utilizes the contrarian index developed by Wei et al. (2008) to measure the extent to which funds trade against the herd among the sample funds. The contrarian index depicts the extent to which fund managers trade with or against the herd.A fund is said to make a contrarian trade if it buys a sell herding stock and sells a buy herding stock. For a trade of a given stock $i$ by fund $j$ in quarter $t$, a signed contrarian measure $C M_{i, j, t}$ that is equal to $R B H M_{\mathrm{i}, \text { tif }}$ the fund sells a "buy herding" stock. On the other hand, $C M_{i, j, t}$ equals $-R S H M_{i, t}$ if the fund sells a "sell herding" stock. A fund level contrarian measure $\operatorname{Con}_{j}$, is constructed, which is the weighted average of $C M_{i, j, t}$ across all trades at time $t$ by mutual fund $j$. The weight is the absolute change of stock $i$ 's weight in fund j given as: 
$\operatorname{CON}_{j, t}=\sum_{i=1}^{N} \omega_{i, j, t} C M_{i, j, t}(4)$

Where $\omega_{i, j, t}$ is given as:

$$
\omega_{i, j, t}=\frac{\left|v_{i, j, t}-v_{i, j, t-1}\right| / v_{j, t}}{\sum_{i=1}^{N}\left|v_{i, j, t}-v_{i, j, t-1}\right| / v_{j, t}}
$$

Where $v_{i, j, t}$ is stock $i$ 's dollar value at quarter tin fund with $v_{j, t}$ being the total net assets of fund $j$ at quarter $t$ and $N$ is the total number of stocks traded by fund $j$. By random chance, a fund may have a high contrarian index, and therefore a rolling average of a mutual fund's contrarian index in the most recent four quarters is used to classify contrarian funds. This will also ensure that the index does not just represent occasional deviations from the herd that may be as a result of a temporary need for liquidity. The rolling average contrarian index is given as:

$$
\operatorname{CON}_{j, t}=\frac{1}{4} \sum_{k=0}^{3} \operatorname{CON}_{j, t-k}
$$

Performance Evaluation: To evaluate performance of mutual funds, the study analyses the changes in net asset values (NAVs) of the mutual funds. The NAV, which is the raw returns of the fund, is defined as the percentage change in the value of the fund for the period, this includes any dividends paid out and the returns are net of expenses (Sinha \& Jog, 2007). Using raw returns is in accordance with Brown, Harlow and Starks (1996) and Chevalier and Ellison (1995) who posit that peer group evaluations of raw returns offer a valid basis for assessing managerial efforts in the fund industry. Initial charges and up-front mandatory fees are excluded in the performance figures.

$$
\frac{N A V_{j, t}-N A V_{j, t-1}}{N A V_{t-1}}
$$

The study uses the geometric mean to arrive at the mean return of funds over the periods under the study. The geometric mean is selected as it is of more significance to long-term investors as it represents the compound rate of return or growth rate of an investment (Gilbertson \& Vermaak, 1982; Hu, 2010).

\section{Results and Discussion}

Results obtained from applying the herd measure (LSV measure) pioneered by Lakonishok, et al. (1991) and the contrarian index developed by Wei, et al. (2008) are presented and discussed below. Further, an analysis of the funds' returns (after expenses) is based on the contrarian indices of funds grouped into quintiles in line with their contrarian indices.

Mutual Fund Herding: LSV Measure: The LSV measure is built on the suggestion that when there is no herding among investors, the expected number of managers who purchase a stock in a given period as a fraction of those who trade the stock, has unchanged value for all stocks. If a significant cross-sectional disparity in the proposal is found, then the null hypothesis of no herding is rejected. Table 1 reports the main results on herding. Based on the central limit theorem, all the results are statistically significant. The mean LSV measure $-0.1406(14.06 \%)$ is one of the main findings of this study.

Table 1: Statistics for herding

\begin{tabular}{lllll}
\hline \multicolumn{2}{l}{ Summary of Herding Measures } & & & \\
& Entire Period & Jun '06 - Jun '08 & Sept '08 - Sept '10 & Dec '10 - Dec '12 \\
\hline Mean & 0.1406 & 0.1353 & 0.1257 & 0.1608 \\
Median & 0.1372 & 0.1349 & 0.1238 & 0.1610 \\
Standard Error & 0.0056 & 0.0053 & 0.0080 & 0.011446 \\
T-test* & 25.16132 & & & \\
\hline
\end{tabular}

${ }^{*}$ Significance at the $1 \%$ level. 
The mean herding measure of $14.06 \%$ denotes that if 100 mutual fund managers traded in the average quarter, then 14.06 more investors traded on one side of the market than expected under the null hypothesis of no herding if these fund managers made their trade decisions randomly and independently of each other. Our measure is more than the reported values of $2.7 \%, 2.5 \%$, and $3.4 \%$ by LSV (1991b), Grinblatt, Titman, and Wermers (1995), and Wermers (1999), respectively. This suggests that mutual fund managers do in fact herd in an average quarter. The herding measures in Table 1 are derived for each quarter and then the average mean herding measure for the whole period and three segments of the period under study are presented.

Contrarian Index: This section presents the findings on the contrarian index for the mutual funds considered in this study over the period 2006 - 2012. The contrarian index measures the degree to which fund managers trade against the herd, with a negative contrarian index signifying a trade with the herd.

Table 2: Statistics for Contrarian Index

\begin{tabular}{lllll}
\hline Quintiles & Index & S. Dev. & S. Error & T-test \\
\hline 1 & 0.3272 & 0.2088 & 0.0402 & $8.1423^{*}$ \\
2 & -0.2071 & 0.1939 & 0.0373 & $-5.5505^{*}$ \\
3 & -0.5266 & 0.2356 & 0.0453 & $-11.6151^{*}$ \\
4 & -0.8424 & 0.2863 & 0.0551 & $-15.2882^{*}$ \\
5 & -1.4944 & 0.4998 & 1.4149 & $-15.5360^{*}$ \\
$1-5$ & 1.8216 & & & \\
\hline
\end{tabular}

${ }^{*}$ Significance at the $1 \%$ level.

Table 2 presents the contrarian indices for the funds and their respective standard deviations, standard errors and the t-tests. Apart from the top quintile (1), it can be observed that all other quintiles have a negative contrarian index, meaning the fund managers in those quintiles were more likely to trade with the herd in an average stock-quarter.

Contrarian Index and Mutual Fund Performance: A major finding in this section is the performance of contrarian funds (quintile 1) and herd funds (quintile 5). For the period $2006-2012$, a statistically significant outperformance of herd funds by contrarian funds was observed. This implies that funds that trade against the herd on average are able to outperform funds that trade with the herd.

Table 3: Contrarian Index and Performance Statistics

\begin{tabular}{llllll}
\hline \multicolumn{2}{l}{ Mutual Fund Returns (Net) } & & & \\
Quintiles & Returns & S. Dev. & S. Error & Critical Values & T-test \\
\hline 1 & 0.0284 & 0.0641 & 0.0123 & 1.4149 & $2.300^{*}$ \\
2 & 0.0270 & 0.0673 & 0.0129 & 1.4149 & $2.085^{*}$ \\
3 & 0.0260 & 0.0728 & 0.0140 & 1.3968 & $1.854^{*}$ \\
4 & 0.0279 & 0.0718 & 0.0138 & 1.4149 & $2.018^{*}$ \\
5 & 0.0234 & 0.0783 & 0.0151 & 1.4149 & $1.552^{*}$ \\
$1-5$ & 0.0050 & & & & \\
\hline
\end{tabular}

${ }^{*}$ Significance at the $1 \%$ level.

On average, contrarian funds outperformed herd funds by $0.5 \%$ per quarter over the period of the study. Another important finding is how herd funds outperformed contrarian funds over the period December 2006 to September 2008 - a period of buoyant growth in the overall economy and a bullish market rally on the JSE - until the period of contraction began. Contrarian funds begin to outperform herd funds since the contraction began and the trend persisted quarter-by-quarter through the recession and even as the period of recovery set in. This finding is in line with Wei et al. (2008) who also found in their study that contrarian funds outperform herd funds by an average of $2.6 \%$ a year in the United States. Gupta-Mukherjee (2012), on 
the other hand, proposes that mutual funds that deviate from their contemporaries underperform. Wei et al. (2008),however, suggest that a possible reason for the disparity in findings is that mutual funds whose portfolios deviate significantly from their contemporaries include both extreme herding funds and contrarian funds.

\section{Conclusion}

The study concludes that mutual fund managers herded in the periods examined. The findings are similar to those investigated by other studies for emerging markets (Gilmour \& Smit, 2002; Lobao and Serra, 2002). This study is unique in that it studies herding and its effects on mutual fund returns in an emerging economy - South Africa - as existing studies investigate herding and its effect on stock prices, and the studies on herding and fund returns are in developed markets. We further found that herd funds underperform contrarian funds. The study grouped funds into quintiles according to their contrarian indices. The contrarian index measures the inclination of a fund to trade in the opposite direction of the crowd. We further compare the performance of contrarian funds and herd funds and discover that contrarian funds outperform herding funds based on their net returns. Contrarian funds outperform herd funds by about $0.005 \%$ per quarter after expenses. We find also that mutual fund investors do not respond to mutual fund performance by investing more in recently performing funds. Findings from this study suggest that contrarian investing is prevalent on the JSE. This further means that the behaviour of these contrarian investors helps stabilize the stock market during turbulent periods. Policy formulation in emerging market economies should support the mutual funds industry by promoting competition in the mutual funds industry. Such action is likely to bring about balanced trade on the bourse which could in turn lead to less volatile markets. Furthermore, the findings show that different funds trade opposite to each other on the JSE. This phenomenon is essential for active equity investors as it promotes astute stock picking skills in the market. Astute stock picking skills help investors realise profits even in a bearish market. The approach used in the study is one of the many approaches that can be used to ascertain the behaviour of mutual funds. A viable alternative for future research is the regression of excess returns from herding and contrarian mutual funds.

Acknowledgements: The authors would like to express their profound gratitude to the two anonymous reviewers for their invaluable contributions that have assisted in shaping this article.

\section{References}

Ang, A., Goetzmann, W. \& Schaefer, S. (2010). The efficient market theory and evidence: implications for active investment management. Foundations and Trends in Finance, 5(3), 157-242.

Baddeley, M., Burke, C., Schultz, W. \& Tobler, P. (2012). Herding in financial behaviour: A behavioural and neuroeconomic analysis of individual differences (Cambridge Working Papers in Economics 1225). Cambrige, UK: University of Cambridge.

Bowe, M. \& Domuta, D. (2004). Investor herding during financial crisis: A clinical study of the Jakarta Stock Exchange. Pacific-Basin Finance Journal, 12(4), 387-418.

Brown, K. C., Harlow, W. V. \& Starks, L. T. (1996). Of tournaments and temptations: An analysis of managerial incentives in the mutual fund industry. The Journal of Finance, 51(1), 85-110.

Chen, G., Rui, O. \& Xu, Y. (2003). When will investors herd? Evidence from the Chinese stock markets. Journal of Financial Research, 37, 2-40.

Chevalier, J. A. \& Ellison, G. D. (1995). Risk taking by mutual funds as a response to incentives(Working Paper No. 5234). Cambridge, MA: National Bureau of Economic Research.

Christie, W. G. \& Huang, R. D. (1995). Following the Pied Piper: Do individual returns herd around the market? Financial Analysts Journal, 51(4), 31-37.

Clare, A. \& Thomas, S. (1995). The overreaction hypothesis and the UK stockmarket. Journal of Business Finance \& Accounting, 22(7), 961-973.

Damodaran, A. (2012). Investment philosophies: Successful strategies and the investors who made them work( $2^{\text {nd }}$ ed.). Hoboken, NJ.: Wiley.

De Bondt, W. F. \& Thaler, R. (1985). Does the stock market overreact? The Journal of Finance, 40(3), 793-805.

De Bondt, W. F. \& Thaler, R. H. (1987). Further evidence on investor overreaction and stock market seasonality. The Journal of Finance, 42(3), 557-581. 
De Haan, L. \& Kakes, J. (2011). Momentum or contrarian investment strategies: Evidence from Dutch institutional investors. Journal of Banking \& Finance, 35(9), 2245-2251.

Demirer, R., Kutan, A. M. \& Chen, C. D. (2010). Do investors herd in emerging stock markets?: Evidence from the Taiwanese market. Journal of Economic Behavior \& Organization, 76(2), 283-295.

Dreman, D. (2012). Contrarian investment strategies: The psychological edge.New York: Simon and Schuster.

Farber, A., Nguyen, V. \& Vuong, Q. (2006). Policy impacts on Vietnam stock market: A case of anomalies and disequilibria 2000-2006. (Universite Libre de Bruxelles CEB Working Paper 06-005.)Brussels, Belgium: Universite Libre de Bruxelles.

Fluck, Z., Malkiel, B. G. \& Quandt, R. E. (1997). The predictability of stock returns: A cross-sectional simulation. Review of Economics and Statistics, 79(2), 176-183.

Gilbertson, B. \& Vermaak, C. (1982). The performance of South African mutual funds: 1974-1981. The Investment Analysts Journal, 20, 35-45.

Gilmour, S. \& Smit, E. (2002). Institutional herding: Evidence from the South African unit trust industry. Investment Analysts Journal, 55(1), 21-35.

Grinblatt, M., Titman, S. \& Wermers, R. (1995). Momentum investment strategies, portfolio performance, and herding: A study of mutual fund behavior. The American Economic Review, 3, 1088-1105.

Gupta-Mukherjee, S. (2012). When active fund managers deviate from their peers: The impact on performance. Unpublished Working Paper. Loyola University.

Hall, A. D. (2010). Getting started in mutual funds( $2^{\text {nd }}$ ed.).Hoboken, NJ: Wiley

Haslem, J. (2009). Mutual funds: Risk and performance analysis for decision making.Hoboken, NJ: Wiley.

Hu, S. P. (2010). Simple mean, weighted mean, or geometric mean?2010 ISPA/SCEA Professional Development and Training Workshop, San Diego, CA, 8 to 11 June 2010. Santa Barbara, CA: Tecolote Research, Inc.

Jensen, M. C. (1968). The performance of mutual funds in the period 1945-1964. The Journal of Finance, 23(2), 389-416.

Kahneman, D., Slovic, P. \& Tversky, A. (1982). Judgment under uncertainty: Heuristics and biases.Cambridge, UK: Cambridge University Press.

Karaban, S. \& Maguire, G. (2012). S\&P Indices Versus Active Funds Scorecard (SPIVA Australia Scorecard). S\&P Dow Jones Indices. Australia: S\&P Dow Jones Indices LLC.

Lakonishok, J., Shleifer, A. \& Vishny, R. W. (1991). Do institutional investors destabilize stock prices? Evidence on herding and feedback trading (NBER Working Paper 3846).Cambridge, MA.: National Bureau of Economic Research.

Lakshman, M., Basu, S. \& Vaidyanathan, R. (2008). Market-wide herding and the impact of institutional investors in the Indian capital market.(IIM Bangalore Research Paper No. 327). Bangalore: Indian Institute of Management.

Lee, B., O'Brien, J. \& Sivaramakrishnan, K. (2010). Availability heuristic and observed bias in growth forecasts: Evidence from an analysis of multiple business cycles. In B. Bruce (Ed.), Handbook of Behavioral Finance(pp. 264-286). Cheltenham, UK; Northampton, MA.: Edward Elgar.

Lobao, J. \& Serra, A. P. (2002). Herding behavior: Evidence from Portuguese mutual funds(Unpublished Working Paper). Instituto de Estudos Financieros e Fiscais, Portugal.

Loughran, T. (2012). On David Dreman's contrarian investment strategies: The psychological edge. Journal of Behavioral Finance, 13(3), 163-163.

Petersen, R. \& Arnstedt, P. (2010). Contrarian investment strategies: An assessment of the value premium in context to recessions. Copenhagen Business School, Department of Finance. Denmark: Institut for Finansiering. Retrieved from http://books.google.co.za/books?id=lMSVtwAACAAJ

Prosad, J. M., Kapoor, S. \& Sengupta, J. (2012). An examination of herd behavior: An empirical evidence from Indian equity market. International Journal of Trade and Economics Finance, 3(2), 154-157.

Quigley, G. \& Sinquefield, R. A. (2000). Performance of UK equity unit trusts. Journal of Asset Management, $1(1), 72-92$.

Scharfstein, D. \& Stein, J. (1990). Herd behavior and investment. American Economic Review, 80, 465-479.

Schwager, J. D. (1992). The new market wizards: Conversations with America's top traders: New York: Wiley.

Schwager, J. D. (2012). The new market wizards: Conversations with America's top tradersHoboken, NJ: Wiley.

Sias, R. W. (2004). Institutional herding. Review of Financial Studies, 17(1), 165-206.

Sinha, R. \& Jog, V. (2007). Fund flows and performance. Canadian Investment Review, 20(2), 28-34. 
Sonaer, G. (2011). Two essays on mutual fund herding.Unpublished doctoral dissertation, Virginia Polytechnic Institute and State University, Blacksburg, Virginia.

Swedroe, L. (2012). Think, act, and invest like Warren Buffett: The winning strategy to help you achieve your financial and life goals.New York: McGraw-Hill.

Tan, L., Chiang, T. C., Mason, J. R. \& Nelling, E. (2008). Herding behavior in Chinese stock markets: An examination of A and B shares. Pacific-Basin Finance Journal, 16(1), 61-77.

Wei, K., Wermers, R. \& Yao, T. (2008). Uncommon value: The investment performance of contrarian funds(Working Paper). University of Texas at Dallas, University of Maryland and University of Iowa.

Wermers, R. (1999). Mutual fund herding and the impact on stock prices. The Journal of Finance, 54(2), 581622.

Wylie, S. (2005). Fund manager herding: A test of the accuracy of empirical results using UK data. The Journal of Business, 78(1), 381-403.

Yalçın, K. C. (2010). Market rationality: Efficient market hypothesis versus market anomalies. European Journal of Economic and Political Studies, 3(2), 23-28. 